\title{
Maatilojen menestyminen ja menestymistekijät
}

\author{
Heikki Mäkinen ${ }^{1)}$, Matti Ylätalo ${ }^{2)}$
}

1) Taloustieteen laitos, PL 27, 00014 Helsingin yliopisto, heikki.makinen@ helsinki.fi

2) Taloustieteen laitos, PL 27, 00014 Helsingin yliopisto, matti.ylatalo@ helsinki.fi

Yrityksen taloudellista menestystä mitataan sen rahaprosessia kuvaavien tilinpäätösaineistojen avulla. Perinteisen tilinpäätösanalyysin käyttökelpoisuutta voidaan parantaa pidentämällä tarkastelun aikajännettä, jolloin pystytään paljastamaan yrityksen talouden nykytila ja kehityssuunta. Tutkimuksen tavoitteena oli tarkastella tilojen menestymistä pitkällä aikavälillä sekä tunnistaa tekijöitä, jotka selittävät menestymiseroja tilojen välillä.

Tutkimusaineistona käytettiin kirjanpitotilojen tilinpäätöstietoja vuosilta 1998-2005. Aineistossa olivat mukana ne maito- $(189 \mathrm{kpl})$ ja viljatilat $(80 \mathrm{kpl})$, joiden päätuotantosuunta oli pysynyt samana em. vuosina. Menestymisen mittarina käytettiin kannattavuuskerrointa.

Tilat luokiteltiin kannattavuuden perusteella kolmeen luokkaan tutkimusjakson alussa ja lopussa, ja tilojen sijoittumista näihin luokkiin tarkasteltiin ristiintaulukoinnin avulla. Maitotiloista $27 \%$ oli pysynyt heikoimmassa ja $15 \%$ parhaassa luokassa. Viljatiloista heikoimpaan luokkaan kuului koko tarkastelujakson ajan $19 \%$ ja parhaimpaan luokkaan $14 \%$. Menestymisluokka jakson lopussa riippui tilastollisesti merkitsevästi menestymisluokasta jakson alussa. Sekä maito- että viljatiloilla putoaminen alempaan kannattavuusluokkaan oli yleisempää kuin nouseminen ylempään luokkaan.

Tilojen kuulumista hyvin tai heikosti menestyneisiin, nousijoihin ja keskiluokkaan selitettiin erotteluanalyysin avulla käyttäen selittävinä tekijöinä muuttujia, jotka ilmentävät viljelijän strategista käyttäytymistä. Tällaisia olivat yrityksen koko ja kasvu, erikoistuneisuuden aste, investointiaktiivisuus, tuottavuuden kehitys ja vieraan pääoman käyttö.

Maitotila-aineistossa muodostui kaksi erottelufunktiota, joilla erotteleviksi muuttujiksi osoittautuivat käyttökateprosentin muutos, omavaraisuusaste jakson alussa ja sen muutos, liikevaihto jakson alussa ja sen muutos, kotieläintuoton osuus liikevaihdosta sekä koneiden nettoinvestointiaste. Ensimmäisen erottelufunktion kuvaama kanoninen ulottuvuus nimettiin suuruuden ekonomiaksi ja toisen kuvaama ulottuvuus kasvuksi. Suuruuden ekonomia -ulottuvuus sai suurimmat arvonsa menestymistään parantaneiden sekä koko ajan menestyneiden tilojen luokassa ja pienimmät arvonsa heikoimmin menestyneiden tilojen luokassa. Kasvu-ulottuvuus sai suurimmat arvonsa menestymistään parantaneiden luokassa.

Viljatiloilla erotteleviksi muuttujiksi osoittautuivat käyttökateprosentin muutos ja koneiden nettoinvestointiaste, joiden muodostama kanoninen ulottuvuus nimettiin tuottavuuden parantamiseksi. Se erotteli menestymisluokat suoraviivaisesti saaden heikosti menestyneiden ryhmässä negatiivisen ja menestyneiden sekä menestymistään parantaneiden ryhmässä positiivisen arvon.

Parhaiten menestyneiden maitotilojen strategian perustana näyttää olleen suuren yrityskoon tuomat hyödyt, johon liittyy keskittyminen kotieläintuotantoon ja sen tuottavuuteen, maltillinen investointikäyttäytyminen sekä hyvä vakavaraisuus. Menestymistään parantaneiden maitotilojen strategian hallitseva piirre on ollut kasvu. Se näkyy sekä liikevaihdon kasvuna, velkaantumisena että investointiaktiivisuutena. Nämä tilat ovat kooltaan lähellä parhaiten menestyneitä tiloja. Mikäli ne selviävät kasvuprosessin tuomasta velkarasitteesta sekä pystyvät parantamaan tuotantoprosessiensa tuottavuutta, niiden voidaan olettaa menestyvän jatkossa entistä paremmin. Heikoimmin menestyneillä tiloilla strategiana näyttää olleen pyrkimys kasvuun, mutta ne eivät ole siinä onnistuneet niin, että se näkyisi menestymisen paranemisena. Ongelmat saattavat liittyä kasvun rajoitteisiin, tuotantoprosessien hallintaan, investointien suuntaamiseen ja velkaantumiseen. Viljatiloilla ainoa havaittu keino parantaa menestymistä oli tuottavuuden parantaminen, mihin liittyy maltillinen investointikäyttäytyminen. Yrityskoolla tai kasvulla ei ollut vaikutusta viljatilojen menestymiseen pitkällä aikavälillä.

Asiasanat: maatila, menestyminen, kannattavuus, strategia, erotteluanalyysi 


\section{Johdanto}

Kysymys yrityksen menestymisestä ja siihen vaikuttavista tekijöistä kuuluu liiketaloustieteen keskeisimpään tutkimusalueeseen. Perinteinen tilinpäätösanalyysi perustuu yrityksen tuloslaskelman ja taseen sekä muiden yritystä koskevien tietojen tutkimiseen. Tilinpäätösanalyysin tavoitteena on erilaisten tunnuslukujen pohjalta arvioida yrityksen taloudellista toimintaa ja pyrkiä ennakoimaan sen kehitystä. Tunnusluvut antavat usein kohtuullisen hyvän kuvan yrityksen taloudellisesta tuloksesta, mutta ne eivät kerro syitä hyvään tai huonoon menestymiseen. Tilinpätösanalyysin tuottaman informaation arvoa voidaan lisätä pidentämällä tarkastelun aikajännettä, jolloin lyhyen aikavälin mahdollisten virheiden merkitys pienenee. Myös yritystutkimuksessa noudatettavien periaatteiden soveltaminen tuo lisäarvoa tilinpäätösanalyysin tuloksiin. Tämä tarkoittaa paitsi yrityksen reaaliprosessin tarkastelua myös strategisten päätösten arviointia, joista haetaan syitä yrityksen hyvälle tai heikolle taloudelliselle menestymiselle.

Tässä tutkimuksessa tarkastellaan maatilojen menestymistä usean vuoden aikavälillä. Tarkoituksena on kuvata, millaista tilojen menestyminen on ollut tällä aikavälillä, tunnistaa menestymisen tai menestymättömyyden kierteessä olevia tiloja sekä etsiä tekijöitä, jotka selittävät tilojen menestymisessä ilmeneviä eroja.

\section{Maatilan menestyminen}

Maatilan menestymisen määrittelyn lähtökohtana voidaan pitää yitystoimintaan liittyvien tavoitteiden saavuttamista. Mitä paremmin asetetut tavoitteet saavutetaan, sitä menestyneempi yritys on. Taloustieteessä yritystoiminnan tavoitteena pidetään taloudellista tehokkuutta, mikä käsitteellisesti pitää sisällään yrityksen voiton eli tuottojen ja kustannusten erotuksen maksimoinnin. Maatilat ovat kuitenkin tyypillisesti perheyrityksiä, joissa tavoitteiden joukko on huomattavan moninainen. Yrittäjäperheen ja liiketoiminnan tavoitteet ovat lisäksi kompleksisessa vuorovaikutuksessa keskenään (Wallace ja Moss, 2002; Olson 2004, 4; Lourenzani et al. 2005). Tavoitteet puolestaan pohjautuvat niihin arvoihin, joita perheyrityksen jäsenillä on, mikä edelleen lisää tavoitejoukon kompleksisuutta ja jopa ristiriitaisuutta. Pelkkiin taloudellisiin mittareihin nojaaminen ei välttämättä sovellukaan pienten maatilojen menestymisen ainoaksi mittariksi (Robinson 2000; Cuykendall ym. 2002; McInerney 2002; Vandermesch ja Mathijs 2004).

Suomessa viljelijät nimesivät Timosen (2000) mukaan tärkeimmiksi tavoitteikseen maataloutta harjoittaessaan tuotteiden hyvän laadun, tuotantokustannuksen alentamisen ja mahdollisimman hyvän kannattavuuden. Sonkkilan $(2002,92)$ tutkimuksessa taas viljelijöiden tärkeimmiksi tavoitteiksi osoittautuivat maksuvalmiuden turvaaminen, tappioiden välttäminen, ympäristöstä huolehtiminen, elämän laadun parantaminen ja riskien välttäminen. Tavoitteiden arvioinnissa käytetyt mittarit olivat näissä kahdessa tutkimuksessa jossain määrin erilaisia, mutta sisälsivät kuitenkin useita samoja elementtejä. Sipiläisen (2003) tutkimuksen haastatteluosion mukaan yrittäjien tavoitteet liittyivät toisaalta kannattavuuteen sekä maksuvalmiuden ja vakavaraisuuden turvaamiseen ja toisaalta tuotannon kestävyyteen ja yritystoiminnan jatkuvuuteen.

Maanviljelijöiden tavoitteiden määrittelyssä kysymys on toisaalta riittävän taloudellisen tuloksen tavoittelusta ja toisaalta halusta elää maanviljelijäperheelle sopivaa elämää. Hyvän taloudellisen tuloksen tavoittelu ei saa johtaa siihen, että perheen elämän laatu heikkenee liikaa, mutta toisaalta taloudellisen tuloksen on oltava niin hyvä, että halutusta elämäntavasta voidaan pitää kiinni. Maatilan menestymistä on siten perusteltua arvioida paitsi talouden tunnuslukujen avulla, myös viljelijän tai viljelijäperheen subjektiivisten arvostusten perusteella. Kuinka hyvin yrittäjäperheen muut kuin taloudelliset tavoitteet voivat toteutua riippuu kuitenkin viime kädessä taloudellisten toimintaedellytysten eli kannattavuuden, vakavaraisuuden ja maksuvalmiuden täyttymisestä. Latukan (1998) tutkimuksessa kannattavuuskerroin osoittautui parhaaksi maatilojen tulorahoituksen riittävyyttä ennustavaksi tekijäksi. Mikäli kohtuullisen tulotason saavuttaminen ja maksuvalmiuden säilyttäminen ovat keskeisiä taloudellisia tavoitteita, on menestymisen mittaamiseen perusteltua käyttää kannattavuutta kuvaavia tunnuslukuja. 


\section{Strateginen suuntautuminen menestymistekijänä}

Maatilan menestymiseen vaikuttavien tekijöiden etsiminen ja tutkiminen on liiketaloustieteen ydinaluetta. Tarkastelu tapahtuu tällöin yrityksen, yrittäjän ja ulkoisen toimintaympäristön luomassa viitekehyksessä. Sen keskiössä on yrittäjä ja hänen kyvykkyytensä tehdä oikeita päätöksiä tuotantoa, markkinointia, rahoitusta ja resurssien hallintaa koskien. Päätöksentekoon liittyvät myös tavoitteiden määrittely, suunnitteluprosessit ja seuranta sekä kontrollointi, joiden avulla tuotetaan informaatiota päätöksenteon tueksi. Ulkoiset tekijät kuten luonnonolot, markkinat ja yhteiskunnan ohjaus vaikuttavat myös olennaisesti siihen, millainen menestyminen on mahdollista saavuttaa ja toisaalta siihen, millaista liikkeenjohtoa yrittäjä toteuttaa.

Strateginen johtaminen muodostaa perustan kaikelle muulle yrityksen johtamiselle keskittyen menestyksen kannalta olennaisimpiin tekijöihin. Strategiseksi voidaan määritellä asiat, jotka koskevat koko yritystä ja joilla on olennainen merkitys sen menestymiselle (Pearson 1990, 20; Neilimo ja UusiRauva 2005). Olsonin (2004) mukaan strategia muodostuu niistä toimenpiteistä, joilla vaikutetaan tilan aseman vahvistamiseen, asiakkaiden tarpeiden tyydyttämiseen ja suorituskykytavoitteiden sekä pitkän aikavälin tavoitteiden toteuttamiseen. Tietoisesti muotoillun strategian avulla viljelijä kykenee sitoutumaan pitkäjänteisesti yritystoimintaan ja sen kehittämiseen epävarmassa toimintaympäristössä. Strategia voidaan nähdä myös polkuna yrityksen nykytilasta haluttuun tilanteeseen (Ondersteijn ym. 2003).

Maatilan strateginen johtaminen on jatkuvasti uudistuva prosessi, joka perustuu yritystoiminnan perimmäisen tehtävän ja tavoitteiden määrittämisen lisäksi tilan resurssien ja ympäristön sekä viljelijän liikkeenjohtokyvyn analysointiin (Kay ja Edwards 1999; Larsen 2003; Olson 2004). Maatilojen liikkeenjohdossa ei riitä pyrkimys asioiden tekeminen oikein, vaan etusijalle on otettava tarkastelu siitä, mikä on maatilayrityksen tilanne ja mihin sitä halutaan viedä. Tehokkuutta eli asioiden oikein tekemistä tarvitaan aina, mutta päämielenkiinnon tulee olla oikeiden asioiden tekemisessä, strategisissa päätöksissä. Mahdollisia strategioita saattaa joillekin tiloille olla olemassa useita, mutta toisilla mahdollisuudet ovat rajallisemmat (Kjesbu ja Flaten 2005).

Pitkällä aikavälillä maatilan menestyminen pohjautuu viljelijän valitsemaan toimintastrategiaan. Menestymisen tai menestymättömyyden syitä on siten perusteltua etsiä yrittäjän strategisesta käyttäytymisestä. Hansen ym. (2005) kuvaavat yrittäjän ominaisuuksien, arvojen ja asenteiden, hänen toteuttamansa strategian ja yritystoiminnan tuloksellisuuden keskinäistä riippuvuutta kuviossa yksi esitetyn mallin avulla. Psykologisen tason tekijät liittyvät viljelijän motivaatioon ja asenteisiin. Niiden pohjalta määräytyvät tavoitteet, joiden saavuttamiseksi yrittäjä luo yrityksensä toimintastrategian. Strategian toteuttaminen on liikkeenjohdollinen tehtävä, ja siinä sekä tuotantoprosessien operationaalisessa johtamisessa onnistuminen määrittää yrityksen tuottavuuden sekä teknisen tehokkuuden, joista puolestaan yhdessä hintasuhteiden kanssa riippuu yrityksen taloudellinen tulos.

Tämä artikkeli on osa laajempaa tutkimushanketta, jossa tarkastellaan maatilan menestykseen vaikuttavia strategisia tekijöitä. Strategiavalinnan kuvaaminen ei kuitenkaan ole yksiselitteistä ensinnäkään siksi, että kaikki yrittäjät eivät välttämättä tee tietoista strategisen tason suunnittelua. Toiseksi yritysten strategiat voidaan jakaa aiottuihin ja toteutuneisiin. Ensinmainitut ovat sellaisia, että ne ovat tarkoituksellisesti luotuja ja yrittäjän on tarkoitus niitä toteuttaa. Jälkimmäiseen ryhmään taas kuuluu se, miten strategiaa on käytännössä toteutettu toimintaympäristön muuttuessa (Grant 1997, ref. Ondersteijn ym. 2003.) Ajatuskulkua edelleen jatkettaessa tullaan siihen, että strategiaa voidaan yrittää arvioida sen pohjalta, mikä näyttäisi olleen yrityksen toiminnan suuntaamisen ohjenuora pitkällä aikavälillä. Tietoisen strategiavalinnan tai -muotoilun merkityksen osoittaminen edellyttää, että käytettävissä on esim. kyselyn avulla hankittua empiiristä aineistoa yrittäjien strategioista. Tässä artikkelissa strategisen suuntautumisen arviointi perustuu kuitenkin eksploratiiviseen analyysiin, jonka perustan muodostivat tilinpäätösaineistosta lasketut tunnusluvut, joiden katsotaan olevan luonteeltaan strategisia, koko yritystä ja sen toiminnan suuntaamista kuvaavia. 


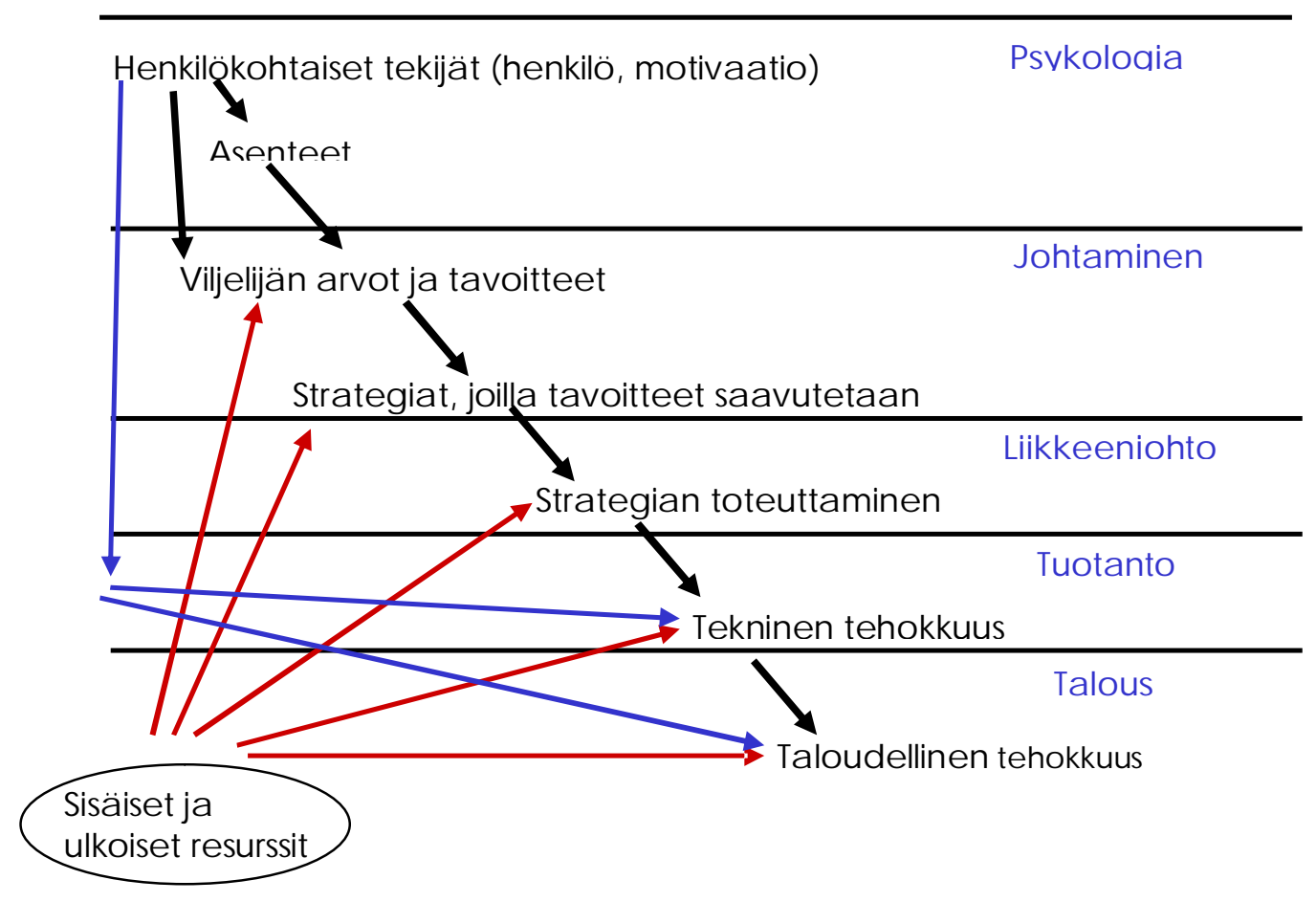

Kuvio 1. Viljelijän taloudellista käyttäytymistä kuvaava malli (Hansen ym. 2005).

\section{Tutkimusaineisto ja menetelmät}

Tutkimusaineistona käytetään MTT Taloustutkimuksen kannattavuuskirjanpitoon kuuluvien tilojen tuloslaskelma-, tilinpäätös- ja tasetietoja vuosilta 1998-2005. Aineistoon otettiin mukaan sellaiset maito- $(189 \mathrm{kpl})$ ja viljatilat $(80 \mathrm{kpl})$, joiden tuotantosuunta on pysynyt samana koko tutkimusjakson ajan. Tarkastelussa halutaan selvittää nimenomaan eri tuotantosuuntia edustavien tilojen menestymistä ajan suhteen ja niiden strategista suuntautumista. Tuotantosuunnan vaihtaminen on käytännössä niin suuri muutos tilan toiminnassa, että sen alle peittyvät oletettavasti kaikki muut strategiavalintoihin ja suuntautumiseen liittyvät seikat.

Menestymisen mittarina päädyttiin käyttämään kannattavuuskerrointa, joka saadaan suhteuttamalla kokonaistuotosta viljelijäperheen omalle työlle ja omalle pääomalle kaikkien muiden kulujen vähentämisen jälkeen jäävä korvaus näille asetettuun palkka- ja korkovaatimukseen. Kannattavuuskertoimen vaihtelu vuodesta toiseen riippuu merkittävästi kasvukauden olosuhteiden vaihteluista etenkin viljatiloilla, mutta jossain määrin myös maitotiloilla. Tätä vaihtelua pyrittiin tasoittamaan käyttämällä peräkkäisten vuosien keskiarvoja. Kannattavuuskerroin tutkimusjakson alussa määritettiin vuosien 1998-2000 kannattavuuskertoimen keskiarvona ja jakson lopussa vuosien 2004-2005 keskiarvona.

Tilat jaettiin jakson alussa tuotantosuunnittain kolmanneksiin kannattavuuskertoimen suuruuden perusteella. Näin määräytyneitä luokkien rajoja käyttämällä tilat jaettiin kolmeen luokkaan vastaavasti myös jakson lopussa, ja yksittäisten tilojen sijoittumista kolmannesten/luokkien kesken tarkasteltiin ristiintaulukoinnin avulla. Ristiintaulukoinnissa erilaisia alku- ja lopputilanteen yhdistelmiä on yhdeksän. Näin ollen tilat jakautuivat yhdeksään menestymisryhmään sen mukaan, olivatko ne pysyneet heikoimmassa, keskimmäisessä tai parhaassa kannattavuusluokassa, tai olivatko ne nousseet parempaan tai pudonneet heikompaan luokkaan. Tilojen kuulumiselle menestymisryhmiin etsittiin selitystä taaksepäin askeltavan erotteluanalyysin avulla käyttäen erottelevina tekijöinä sellaisia tase- ja tilinpäätöstiedoista laskettuja muuttujia, joiden katsottiin voivan kuvata viljelijöiden strategista suuntautumista. Erottelevat muuttujat määritettiin seuraavasti:

\begin{tabular}{|l|l|}
\hline $\begin{array}{l}\text { Tilan koko jakson alus- } \\
\text { sa: }\end{array}$ & liikevaihto vuosien 1998-2000 keskiarvona sekä viljelyala vuonna 1998. \\
\hline Tilan kasvu: & $\begin{array}{l}\text { liikevaihdon suhteellinen kasvu jakson aikana sekä peltoalan suhteellinen } \\
\text { kasvu jakson aikana }\end{array}$ \\
\hline
\end{tabular}




\begin{tabular}{|l|l|}
\hline Investointiaktiivisuus: & $\begin{array}{l}\text { koneiden ja rakennusten poistamattoman menojäännöksen muutos jakson } \\
\text { aikana suhteessa jalostusarvojen summaan (jalostusarvo saadaan lisäämäl- } \\
\text { lä käyttökatteeseen maksetut palkat ja viljelijäperheen palkkavaatimus) }\end{array}$ \\
\hline Tuottavuuden muutos: & $\begin{array}{l}\text { tilan käyttökateprosentin suhteellinen muutos vuosien 1998-2000 keskiar- } \\
\text { vosta vuosien 2004-2005 keskiarvoon }\end{array}$ \\
\hline $\begin{array}{l}\text { Vieraan pääoman käyt- } \\
\text { tö: }\end{array}$ & omavaraisuusaste keskimäärin vuosina 1998-2000 \\
\hline $\begin{array}{l}\text { Vieraan pääoman käy- } \\
\text { tön muutos: }\end{array}$ & omavaraisuusasteen muutos jakson aikana prosenttiyksiköinä \\
\hline $\begin{array}{l}\text { Keskittyminen ydintoi- } \\
\text { mintaan: }\end{array}$ & $\begin{array}{l}\text { maitotiloilla kotieläintuoton ja viljatiloilla kasvinviljelytuoton osuus liike- } \\
\text { vaihdosta ilman tukia koko jakson keskiarvona }\end{array}$ \\
\hline
\end{tabular}

\section{Tulokset}

Ristiintaulukointi tilojen sijoittumisesta kannattavuuskolmanneksiin tutkimusjakson alussa sekä vastaavin raja-arvoin määritettyihin luokkiin tutkimusjakson lopussa on esitetty taulukossa 1 . Maitotiloista alimpaan kolmannekseen kuuluvat tilat, joilla kannattavuuskerroin oli pienempi kuin 0,558. Ylimpään kolmannekseen kuuluvilla maitotiloilla kannattavuuskerroin oli suurempi kuin 0,746 . Viljatiloilla vastaavat raja-arvot olivat 0,259 ja 0,651 .

Taulukko 1. Tilojen sijoittuminen kolmeen kannattavuusluokkaan tutkimusjakson alussa ja lopussa (havaintojen lukumäärä ja vastaava prosenttiluku).

\begin{tabular}{lllll}
\hline Maitotilat $(\mathrm{n}=189)$ & \multicolumn{4}{l}{} \\
& \multicolumn{4}{c}{ Kannattavuusluokka jakson lopussa } \\
$\begin{array}{l}\text { Kannattavuusluokka } \\
\text { jakson alussa }\end{array}$ & alin & keski & ylin & Yht. \\
\hline alin & 51 & 7 & 5 & 63 \\
& 27,0 & 3,7 & 2,7 & 33,3 \\
keski & 31 & 24 & 8 & 63 \\
& 16,4 & 12,7 & 4,2 & 33,3 \\
ylin & 12 & 22 & 29 & 63 \\
& 6,4 & 11,6 & 15,3 & 33,3 \\
\hline Yhteensä & $\mathbf{9 4}$ & $\mathbf{5 3}$ & $\mathbf{4 2}$ & $\mathbf{1 8 9}$ \\
\hline
\end{tabular}

Viljatilat $(\mathrm{n}=80)$

\begin{tabular}{lllll}
\hline \multirow{2}{*}{$\begin{array}{l}\text { Kannattavuusluokka } \\
\text { jakson alussa }\end{array}$} & alin & keski & ylin & Yht. \\
\hline alin & 15 & 9 & 2 & 26 \\
& 18,8 & 11,3 & 2,5 & 32,5 \\
keski & 9 & 12 & 6 & 27 \\
& 11,3 & 15,0 & 7,5 & 33,8 \\
\multirow{2}{*}{ ylin } & & & & \\
& 6 & 10 & 11 & 27 \\
\hline Yhteensä & 7,5 & 12,5 & 13,8 & 33,8 \\
\hline
\end{tabular}

Kannattavuus tutkimusjakson alussa ja lopussa korreloivat tilastollisesti merkitsevästi keskenään sekä maito- että viljatiloilla. Tutkimusjakson alussa kaikissa kannattavuusluokissa oli 63 maitotilaa. Kannattavuuskehitys on tutkimusjakson aikana ollut heikkenevä, sillä alimpaan kannattavuusluokkaan kuului jakson lopussa jo puolet tiloista (94). Toisaalta kuitenkin osa jakson alussa heikosti menestyneistä tiloista oli noussut jakson loppuun mennessä ylempään kannattavuusluokkaan. $X^{2}$-testin mukaan maitotilojen sijoittumisessa kannattavuusluokkiin jakson alun ja lopun kesken oli tilastollisesti 
erittäin merkitsevä riippuvuus $\left(\mathrm{X}^{2}=58,5, \mathrm{p}<0,0001\right)$. Tilastollinen riippuvuus, joskaan ei yhtä voimakas oli havaittavissa myös viljatilojen ryhmässä $\left(X^{2}=11,1, p=0,025\right)$. Samoin siirtymiä heikompaan kannattavuusluokkaan oli viljatilajoukossa enemmän kuin siirtymiä parempaan luokkaan.

Aineiston suhteellisen pieni koko ja menestymisryhmien suuri määrä (9) on ongelma erotteluanalyysin kannalta, koska pienimmissä ryhmissä oli havaintoja vähemmän kuin mahdollisia erottelevia muuttujia. Tämä johtaa tutkittavan ilmiön ylimallintumiseen pienimmissä ryhmissä (esim. Metsämuuronen 2005, 790). Niinpä ennen lopullisen erotteluanalyysin tekemistä alkuperäiset yhdeksän ryhmää yhdistettiin neljäksi suuremmaksi ryhmäksi. Ryhmien uudelleenmuodostaminen perustui alustavaan erotteluanalyysiin kaikkien yhdeksän ryhmän kesken sekä erottelevien tekijöiden varianssianalyysiin. Uusia ryhmiä muodostettiin neljä:

1. heikosti menestyneiksi luokiteltiin tilat, jotka olivat pysyneet koko ajan alimmassa kannattavuusluokassa tai olivat pudonneet siihen keskimmäisestä tai parhaasta luokasta (maitotiloja 94, viljatiloja 30)

2. nousijoiksi luokiteltiin tilat, jotka olivat nousseet ylempään kannattavuusluokkaan (maitotiloja 20, viljatiloja 17)

3. keskiryhmään kuuluviksi luokiteltiin koko ajan keskimmäisessä luokassa pysyneet tai keskiluokkaan ylimmästä luokasta pudonneet tilat (maitotiloja 46, viljatiloja 22)

4. menestyjiksi luokiteltiin koko ajan ylimmässä kannattavuusluokassa pysyneet tilat (maitotiloja 29, viljatiloja 11)

Taaksepäin askeltavassa maitotila-aineiston erotteluanalyysin tulokseksi saatiin kolme erottelufunktiota, joista kaksi ensimmäistä oli tilastollisesti merkitseviä. Näistä ensimmäinen kattoi noin $74 \%$ ja toinen noin $19 \%$ ryhmien välisestä vaihtelusta. Erottelukykyisiksi osoittautui seitsemän muuttujaa: käyttökateprosentin muutos, omavaraisuusaste jakson alussa, omavaraisuusasteen muutos, liikevaihto jakson alussa, liikevaihdon kasvuprosentti, kotieläintuoton osuus liikevaihdosta ilman tukia sekä koneiden nettoinvestointiaste.

Erottelufunktioiden luokittelukyky oli melko alhainen, sillä funktioiden avulla kyettiin uudelleenluokittelemaan oikein noin $56 \%$ havainnoista. Suurin osa virheluokituksista osui kuitenkin "viereiseen" luokkaan, sillä heikoimpaan luokkaan kuuluneista 17\% (16 tilaa) luokittui keskiluokkaan, keskiluokkaan kuuluneista 24\% (11 tilaa) luokittui menestyjiin, menestyjistä 38\% (11 tilaa) luokittui keskiluokkaan ja nousijoista 25\% (5 tilaa) luokittui keskiluokkaan. Erottelumallin taipumus luokitella havainnot viereiseen luokkaan on ymmärrettävää, sillä alkuperäinen jako menestymiskolmanneksiin on jossain määrin mielivaltainen: ryhmien välinen raja joudutaan vetämään jatkuvan muuttujan arvojen perusteella kahden havainnon väliin, jotka kuitenkin todellisuudessa saattavat olla lähes identtisiä.

Viljatiloilla erotteleviksi muuttujiksi osoittautuivat ainoastaan käyttökateprosentin muutos ja koneiden nettoinvestointiaste. Erottelufuktioita erottui kaksi, joista vain ensimmäinen oli tilastollisesti merkitsevä. Se kattoi 94\% ratkaisun varianssista. Erottelufunktioiden avulla kyettiin luokittelemaan oikein 53\% tiloista. Myös viljatiloilla luokittelumallilla oli taipumus luokitella havainnot keskiryhmään.

Kanoniset erottelufunktiot kuvaavat niitä erottelevien muuttujien kombinaatioita, joiden suhteen ryhmät eroavat toisistaan. Erottelufunktioiden standardoidut painokertoimet on esitetty taulukossa 2. Maitotila-aineistossa ensimmäisellä kanonisella erottelufunktiolla suurimmat positiiviset painot saavia selittäjiä olivat: käyttökateprosentin muutos, omavaraisuusaste tutkimusjakson alussa, omavaraisuusasteen muutos ja liikevaihto jakson alussa sekä kotieläintuoton osuus liikevaihdosta ilman tukia. Negatiivisen painon sai koneiden nettoinvestointiaste. Näiden tekijöiden voidaan katsoa kuvaavan suurta kokoa, alhaista suhteellista investointiaktiivisuutta ja tuotantoprosessien tehokkuuden parantamista, joten ensimmäisen kanonisen muuttujan nimeksi annettiin suuruuden ekonomia. Toisella kanonisella erottelufunktiolla liikevaihdon kasvuprosentti sai suuren positiivisen painon. Kaikkien muiden selittävien tekijöiden painot olivat negatiivisia ja suhteellisen lähellä nollaa, mutta ne poikkesivat olennaisesti vastaavien tekijöiden ensimmäisellä kanonisella funktiolla saamista painoista. Toinen kanoninen muuttuja kuvasi siten voimakasta kasvua, suhteellista velkaantumista ja sen lisääntymistä sekä ensimmäistä muuttujaa voimakkaampaa investointiaktiivisuutta, joten sen kuvaaman ulottuvuuden nimeksi annettiin kasvu.

Viljatilojen ainoalla merkitsevällä erottelufunktiolla käyttökateprosentin muutoksen standardoitu painokerroin oli 0,95 ja koneiden nettoinvestointiasteen -0,52. Näiden kuvaaman kanonisen muuttu- 
jan nimeksi annettiin tuottavuuden paraneminen.

Taulukko 2. Erottelufuntioiden standardoidut painokertoimet (kanoniset erottelufunktiot).

\begin{tabular}{lll|l}
\hline & Maitotilat & Viljatilat \\
\hline & $\begin{array}{l}\text { F1: } \\
\text { "Suuruuden } \\
\text { nomia" }\end{array}$ & $\begin{array}{l}\text { F2: } \\
\text { eko- "Kasvu" }\end{array}$ & $\begin{array}{l}\text { F1: } \\
\text { "Tuottavuuden } \\
\text { paraneminen" }\end{array}$ \\
\hline $\begin{array}{l}\text { käyttökateprosentin muutos } \\
\text { omavaraisuusaste alkuvuosina }\end{array}$ & 0,80 & $-0,13$ & 0,95 \\
omavaraisuusasteen muutos & 0,50 & $-0,35$ & -- \\
liikevaihto alkuvuosina & 0,46 & $-0,19$ & -- \\
liikevaihdon kasvuprosentti & 0,06 & $-0,17$ & -- \\
kotieläintuoton osuus liikevaihdosta & 0,34 & 0,96 & -- \\
koneiden nettoinvestointiaste & $-0,46$ & $-0,15$ & -- \\
\hline
\end{tabular}

Eri menestymisryhmiin kuuluvien maitotilojen sijoittumista suhteessa kanonisiin muuttujiin tarkasteltaessa (kuvio 2) voidaan havaita, että ensimmäisen kanonisen muuttujan kuvaama ulottuvuus "suuruuden ekonomia" sai suurimmat arvonsa menestymistään parantaneiden sekä koko ajan menestyneiden tilojen ryhmissä ja pienimmät arvonsa heikoimmin menestyneiden tilojen ryhmässä. Toisen kanonisen muuttujan kuvaama ulottuvuus "kasvu" puolestaan sai suurimmat arvonsa tyypillisesti menestymistään parantaneiden ryhmässä. Muiden ryhmien kesken tässä ulottuvuudessa ei ollut olennaisia eroja, vaikkakin heikoimmin menestyneiden ryhmässä kasvu-ulottuvuus oli hieman voimakkaampi kuin keskiryhmässä tai menestyneiden ryhmässä. Ryhmien päällekkäisyys erottelufunktioiden muodostamassa avaruudessa on hyvin voimakasta, mitä kuvaa myös mallin heikko uudelleenluokittelukyky.

Kasvu

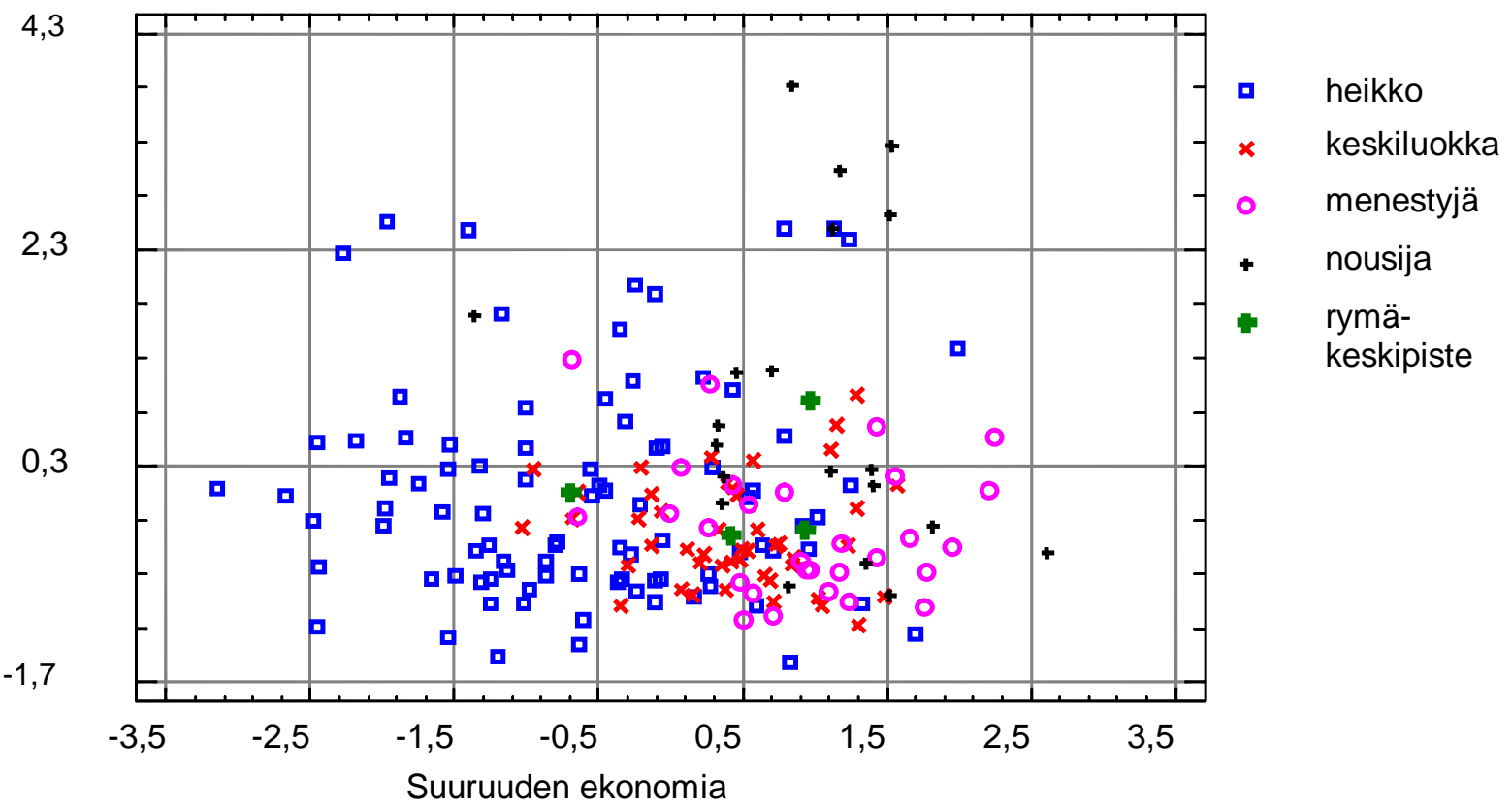

Kuvio 2. Maitotilojen sijoittuminen kanonisilla erottelufunktioilla.

Tuottavuuden paraneminen erotteli viljatilat (kuvio 3) menestymisryhmiin suoraviivaisesti siten, että heikosti menestyneiden ryhmässä ja keskiryhmässä ko. kanoninen muuttuja saa negatiivisen arvon ja menestyneiden sekä menestymistään parantaneiden ryhmässä positiivisen arvon. Menestymistään parantaneiden ryhmä erottuu erityisen selvästi, mutta ryhmien päällekkäisyys on huomattavan suurta. (Kuviossa kolme y-akseli F2 kuvaa viljatilojen toisen kanonisen erottelufunktion arvoja. Sen sisällöllinen tulkinta ei kuitenkaan ole mielekästä, koska se ei osallistu merkitsevästi ryhmien erotteluun.) 




Kuvio 3. Viljatilojen sijoittuminen kanonisilla erottelufunktioilla.

\section{Johtopäätökset}

Tulosten perusteella näyttää siltä, että tutkimusajanjaksolla parhaiten menestyneiden maitotilojen ryhmässä strategian perustana on ollut suuren yrityskoon tuoma hyöty, keskittyminen kotieläintuotantoon ja sen tuottavuuteen, maltillinen investointikäyttäytyminen sekä hyvä vakavaraisuus. Yrityskoon kasvun suhteen ne eivät juurikaan poikkea heikommin menestyneistä tiloista. Menestymistään parantaneiden maitotilojen strategian hallitseva piirre on ollut kasvu, joka näkyy sekä liikevaihdon voimakkaana kasvuna, velkaantumisena että investointiaktiivisuutena. Nämä tilat ovat kooltaan keskimäärin lähellä parhaiten menestyneitä tiloja. Voidaankin olettaa, että mikäli ne selviävät kasvuprosessin tuomasta velkarasitteesta sekä pystyvät parantamaan tuotantoprosessiensa tuottavuutta, niiden on mahdollista parantaa kannattavuuttaan. Heikoimmin menestyneillä maitotiloilla strategiana näyttää olleen pyrkimys kasvuun, mutta ne eivät ole onnistuneet siinä niin hyvin, että kasvu näkyisi menestymisen olennaisena paranemisena. Ongelmat saattavat liittyä niin tilakohtaisiin kasvun rajoitteisiin, tuotantoprosessien hallintaan, investointien suuntaamiseen kuin velkaantumiseenkin. Mainitut ongelmat saattavat ilmentää myös yrittäjän puutteellista liikkeenjohtokykyä.

Viljatiloilla ainoa tässä tutkimuksessa havaittu keino parantaa menestymistä on ollut tuottavuuden parantaminen, mihin liittyy hyvin maltillinen investointikäyttäytyminen. Sen sijaan yrityskoolla tai kasvulla - mitattiinpa sitä viljelyalalla tai liikevaihdolla - ei ollut havaittavaa vaikutusta menestymiseen.

Tutkimushankkeen jatkuessa mielenkiinto kohdistuu yksittäisten tilojen tuotantoprosessien tarkasteluun sekä strategisen ajattelun ja sen suuntautumisen arvioimiseen eri menestymisryhmiin kuuluvia viljelijöiltä haastattelemalla. Myös strategiseen suuntautumisen tarkastelua laajennetaan ja syvennetään ottamalla huomioon mm. tilojen resurssien käyttöön liittyviä tekijöitä.

\section{Kirjallisuus}

Cuykendall, C., LaDue, E. \& Smith, R. D. 2002. What Successful Small Farmers Say.The Results of A Survey of Successful Small Farm Operators. Department of Applied Economics and Management, College of Agriculture and Life Sciences, Cornell University. 96 p.

Grant, R. M. 1997. Contemporary Strategic Analysis: Concepts, Techniques, Applications. Blackwell Publishers, Oxford. 
Hansen, B., Stokstad, G., Hegrenes, A., Sehested, E. \& Larsen, S. 2005. Key Performance Indicators on Dairy Farms. Journal of International Farm Management Vol.3. No.1 - July 2005

Kjesbu, E. \& Flaten, O. 2005. Perceptions and impacts of Fram-A: A Norwegian Farm Business Development Programme. Congress Proceeding, 15th International Farm Management Conference August 14th to 19th, 2005. $4 \mathrm{p}$

Larsen, T. 2003. implementation of Strategic Planning to Local Consultants - FarmStrat by DAAC. Teoksessa: Hegrenes, A. (ed) 2003. Farm Management. Proceedings of NJF Seminar No. 345, 2-4 October 2002. ss.59-65.

Latukka, A. 1998. Maatalousyritysten tulorahoituksen riittävyyden ennustaminen neuroverkkomenetelmällä. Helsingin yliopisto, Taloustieteen laitos, julkaisuja nro 22: 1-138.

Lourenzani, W., Queiroz, T. \& de Souza Filho, H. 2005. Strategic Mapping Of The Rural Firm: A Balanced Scorecard Approach. Congress Proceeding, 15th International Farm Management Conference August 14th to 19th, 2005. $8 \mathrm{p}$

McInerney, J. 2002. Re-orienting Uk Agriculture. Farm management Vol. 11, No. 4: 217-231.

Metsämuuronen, J. 2005. Tutkimuksen tekemisen perusteet ihmistieteissä. 3. painos. Gummerus Kirjapaino Oy, Jyväskylä. 1292 s.

Neilimo, K. \& Uusi-Rauva, E. 2005. Johdon laskentatoimi. 366 s. Helsinki.

Olson, K. 2004. Farm Management. Principles and Strategies. 429 s. Iowa.

Ondersteijn, C., Giesen, G. \& Huirne, R. 2003. Identification of Farmer Characteristics and Farm Strategies Explaining Changes in Environmental Management and Environmental and Economic Performance of Dairy Farms. Agricultural Systems 78: 31-55.

Pearson, G. J. 1990. Strategic Thinking. 237 s. Exeter.

Robinson, M. 2000. Clarification and Identification of Relevant Business Objektives. Farm Management Vol 10, No. 8: 486-498.

Sipiläinen, T. 2003. Suurten maito- ja viljatilojen suorituskyky ja sen kehittäminen. Helsingin yliopisto, Taloustieteen laitos, julkaisuja nro 38: 1-90.

Sonkkila, S. 2002. Farmers' decision making on adjustment into the EU. University of Helsinki, Department of Economics and Management, publications No 34: 1-160.

Timonen, R. 2000. Yrittäjyys, liikkeenjohto ja menestyminen maatilayrityksissä. Helsingin yliopisto, Taloustieteen laitos, julkaisuja nro 28: 1-234.

Wallace, M. \& Moss, J. 2002. Farmer Decision-Making with Conflicting Goals: A Recursive Strategic Programming Analysis. J. of Agric. Econ. Vol. 53, No 1: 82-100.

Vandermersch, M. \& Mathijs, E. 2004. The Impact of Management Attitudes on The Financial Performance of Flemish Dairy Farms. Farm Management Vol. 11 No. 11: 637-648. 